\title{
Sexualities and queer migration research
}

\section{Richard Mole, UCL SSEES}

For the past five years my research has focused on the relationship between migration and sexuality - from migrant sexual health and sexual resocialisation to the formation of queer diasporas and experience of queer asylum seekers - and research published in Sexualities has played a significant role in providing me with the theoretical and conceptual tools I needed to follow existing debates, carry out my own research and make sense of my data.

Until relatively recently, the academic study of migration did not explicitly deal with sexual difference, implicitly assuming the 'typical migrant' to be heterosexual. In recent years, these assumptions have been challenged by scholars who have produced a small but growing literature on the migration experiences of LGBTQ subjects. My own interest in the intersections between non-normative sexualities and mobility was driven by a number of factors. Theoretically, I was intrigued by Martin Manalansan's claim that the very idea of queer had to a significant extent been brought about by migration in that the mass movement of people to the West from various non-Western cultures had brought into sharp relief the numerous 'sexual identity categories and practices that [did] not depend on Western conceptions of selfhood and community', thereby producing a range of queer identities and subjectivities (2006, 229). Empirically, as an East Europeanist, I found it striking that so much research on queer migration focused on the United States, with some attention also paid to Asian and Latin American societies as sending countries, but that little research had been conducted on migration by LGBTQ subjects to or within Europe, let alone Eastern Europe. This was surprising given the disparities in attitudes towards and the degree of legal protection for LGBTQ people across Europe and thus the extent to which differences in said attitudes and rights could potentially act as push or pull factors in sending and receiving states, respectively. In addition, within the European Union at least, queer citizens had the right to free movement and did not therefore face the legal hurdles of most migrants seeking to enter the US.

These factors thus prompted me to explore whether and to what extent the decisions of migrants from the former communist states of Central and Eastern Europe to move abroad had been prompted by their sexuality and whether living outside of their homelands had an impact on their identities and behaviours, including their sexual behaviours. Before embarking on this research, I wanted to make sure that my ideas were grounded in the latest literature on sexuality and migration and thus turned, as I often did, to the Sexualities back catalogue. Looking through the first 15 years of the journal, I found a number of useful articles (Runganga and Aggleton, 1996; Shahidian, 1999; Bredström, 
2005) that provided me with the theoretical and conceptual tools I needed to conduct my first research projects on the sexual health and sexual behaviour of LGBTQ migrants (Mole et al., 2013).

The breadth of research on queer migration published in Sexualities increased from 2013, when Feona Attwood, Róisín Ryan-Flood and Travis SK Kong took over the editorial reins from Ken Plummer after his 18 highly successful years at the helm and identified 'Migration, diaspora and post-colonialism' - including 'sexualities and exile, in the journeys of refugees, nomads and migrants, and in diaspora' - as a topic they thought deserved greater academic attention (Attwood, Ryan-Flood and Kong, 2013, 765). The following year, in response to this call, Rachel Lewis and Nancy Naples published of a special issue of the journal dedicated to 'Queer Migration, Asylum and Displacement'. I remember reading this special issue while sifting through the transcriptions of my own interviews with queer Polish and Russian migrants in London and Berlin, and the ideas discussed in the various articles - particularly with reference to the ways in which 'sexuality, in relation to hierarchies of race, class, gender, and nation structures processes of international migration and border-crossing' - helped me frame my own analysis (Lewis and Naples, 2014, 912; emphasis added). It prompted me to examine the intersectionality of nationality and sexuality, showing how national norms and values can be used instrumentally by social and political actors in the home country to marginalise and discriminate against sexual minorities, thereby constituting a potential push factor for migration, but at the same time demonstrating how national consciousness could provide a sense of community and belonging for queer migrants living in a foreign cultural environment. These ideas served as the springboard for my own research on the potential benefit of 'queer diaspora' as a heuristic device to think about identity, belonging and solidarity among sexual minorities in the context of dispersal and transnational networks (Mole, 2018). Furthermore, four of the articles in the special issue - by Shuman and Bohmer, Shuman and Hesford, Shakhsari, and Lewis herself - introduced me to the challenges facing queer asylum seekers and the way some 'lesbian and gay liberal rights discourses produce narratives of progress and modernity', thereby creating moral hierarchies vis-à-vis national, racial and religious Others (Puar, 2013, 25). Bringing together my interests in nationalism, sexuality and migration, these debates fed into a special issue I edited for Sexualities on 'Homonationalism' (2017), with the articles building on Puar's insights and applying them to a broad range of themes, policy areas and case studies in Europe, North America, Africa and the Middle East - with a particular focus on migrant populations. 
Sexualities' well-deserved reputation as the leading journal in the study of sexualities is thus in no small part thanks to the editors' ability to identify and promote topics worthy of special attention, and long may the journal continue to set the pace in queer migration research.

\section{Bibliography}

Manalansan, M.F. (2006) 'Queer intersections: sexuality and gender in Migration Studies', International Migration Review, vol. 40, 224-249

Mole, R.C.M. (2018) 'Identity, belonging and solidarity among Russian-speaking queer migrants in Berlin', Slavic Review, vol. 77 [forthcoming]

Mole, R.C.M., Parutis, V., Gerry, C.J. and Burns, F.M. (2013) 'The impact of migration on the sexual health, behaviours and attitudes of Central and East European gay/bisexual men in London', Ethnicity and Health, vol. 19, no. 1, 86-99

Puar, J.K. (2013) 'Homonationalism as assemblage: viral travels, affective sexualities', Jindal Global Law Review, vol.

$$
4,23-42
$$

